10IKC-366

\title{
PALAEOPROTEROZOIC ULTRAMAFIC LAMPROPHYRES AND ASSOCIATED CARBONATITES FROM THE MAHAKOSHAL SUPRACRUSTAL BELT, CENTRAL INDIA: EVIDENCE FOR A CARBONATE-RICH METASOMATISED MANTLE
}

\author{
Srivastava RK, Gautam GC \\ Centre of Advanced Study, Department of Geology, Banaras Hindu University, Varanasi 221005, India
}

\begin{abstract}
Blichert-Toft et al. (1995) have rightly stated that alkaline-carbonatite magmatism is rare in the Precambrian geological record. This is possibly because (i) either they are derived from very small amount of melts and did not survive through time (ii) or conditions for generation of such melts were not suitable (iii) or lower $\mathrm{CO}_{2}$ contents in melting regions did not supported formation of silicaundersaturated magmas, and (iv) or the absence of metasomatized lower lithosphere prohibited the formation of rift-type magmas. The detailed study of such rocks is important to understand nature of the subcontinental mantle. Association of lamprophyre, particularly ultramafic lamprophyre with carbonatite is reported by many workers (Blichert-Toft et al., 1995; Vichi et al., 2005; Tappe et al., 2006 and references therein). It is wellknown that ultramafic lamprophyres can carry appreciable amount of carbonate (up to about 40 vol.\%) but low $\mathrm{SiO}_{2}$ contents, therefore their association with carbonatite is frequent (Vichi et al., 2005; Tappe et al., 2006). Ultramafic lamprophyres (UML) commonly occur as dyke or plug (Rock, 1991). In this work we present petrological and geochemical characteristics of Palaeoproterozoic dykes and plugs of ultramafic lamprophyre (UML) and associated carbonatite from the Mahakoshal supracrustal belt (Fig. 1) to understand the petrogenesis of this suite.
\end{abstract}

A number of mafic-ultramafic, alkaline and carbonatite dykes and plugs are well exposed within the Mahakoshal supracrustal belt (Fig. 1; Jain et al., 1995; Nair et al., 1995). Roy and Chakraborty (2008) classified these ultramafics as lherzolitic peridotite, wehrlite and dunite. Srivastava and Chalapathi Rao (2007) have reported alkaline lamprophyre from the Jungel area. There is no radiometric age data on studied rocks is available to confirm this inference, however, the available geochronological data on different rocks units of the Mahakoshal greenstone belt, an intrusive syenite, associated alkali gabbro, and lamprophyre suggest emplacement of studied UML during Late Paleoproterozoic $(\sim 1.6 \mathrm{Ga})$ (Nair et al., 1995; Srivastava and Chalapathi Rao, 2007). Srivastava and Chalapathi Rao (2007) reported presence of a wide spectrum of undersaturated alkaline magmatism comprising lamprophyres, highly carbonated rocks (carbonatites?) and ultrabasic rocks as intrusives in to the Mahakoshal supracrustal belt. This evidently suggests the presence of a carbonaterich paleo- to early-Proterozoic alkaline province in this region.

Study of thin sections of UML and carbonatites clearly indicate effect of low-grade metamorphism and hydrothermal alterations. Due to these post-magmatic processes it is difficult to 


\section{$10^{\text {th }}$ International Kimberlite Conference, Bangalore - 2012}

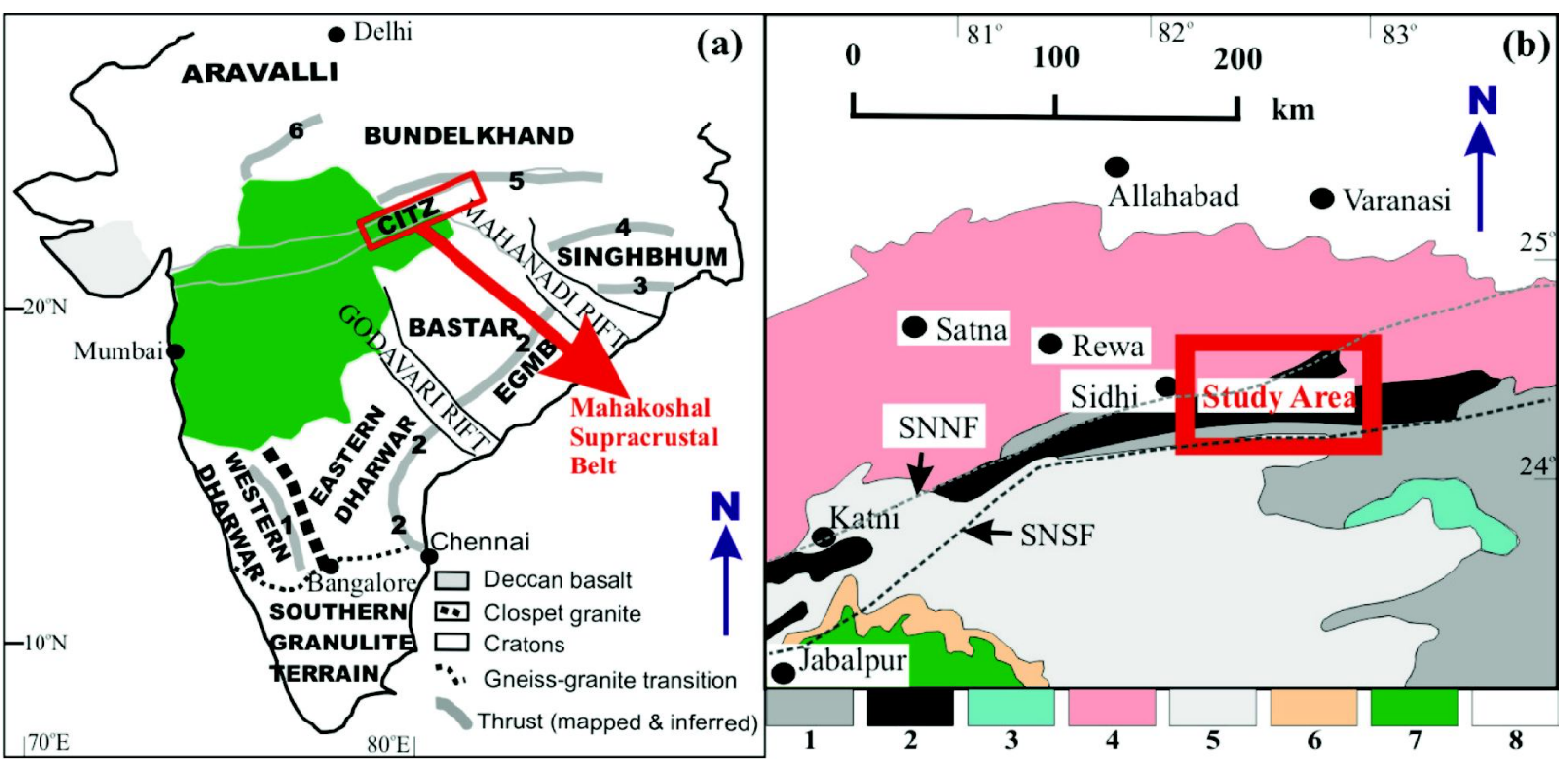

Fig. 1: (a) Major cratons and structural features of India (after Naqvi and Rogers, 1987). CITZ: Central Indian Tectonic Zone; EGMB: Eastern Ghats Mobile Belt. Major structural features are: 1. Small thrusts in western Dharwar craton, 2. Eastern Ghat front, 3. Sukinda, 4. Singhbhum, 5. Son Valley, and 6. Great Boundary fault. (b) Simplified geological map of a part of the northeastern portion of Central India (taken from Roy et al., 2000). 1. Granitoids (gneisses, migmatites and granulites), 2. Palaeo- to Mesoproterozoic Mahakoshal supracrustal belt, 3. High-grade gneiss-supracrustal and medium grade metasedimetaries equivalent to DongargarhGroup, 4. Meso- to Neoproterozoic Vindhyan Supergroup, 5. Gondwana Supergroup, 6. Lameta Group, 7. Deccan basalts, and 8. Quaternary and Recent sediments. SNNF: Son-Narmada North Fault; SNSF: Son-Narmada South Fault.

observe any fresh igneous minerals; however, most rocks still retain their primary igneous textures. Pseudomorphs of olivines, phlogopite and pyroxenes are observed in most of the UML samples. Primary minerals like mica and amphiboles are almost completely altered, however, almost all the studied ultramafic rocks retain their original igneous textures; most show porphyritic texture. The main phenocrysts reported in these rocks are olivine (Fig. 2), phlogopite, and minor pyroxene.

Most significant feature observed in a number of thin sections is presence of volatile rich minerals; particularly rounded or elliptical carbonate ocelli (Fig. 3a \& b). It is possible that some calcite is secondary; however presence of carbonate-rich ocelli is a good candidate to support presence of magmatic carbonate. These distinguished characteristics clearly recognize these rocks as ultramafic lamprophyres, specifically aillikites (carbonate-rich ultramafic

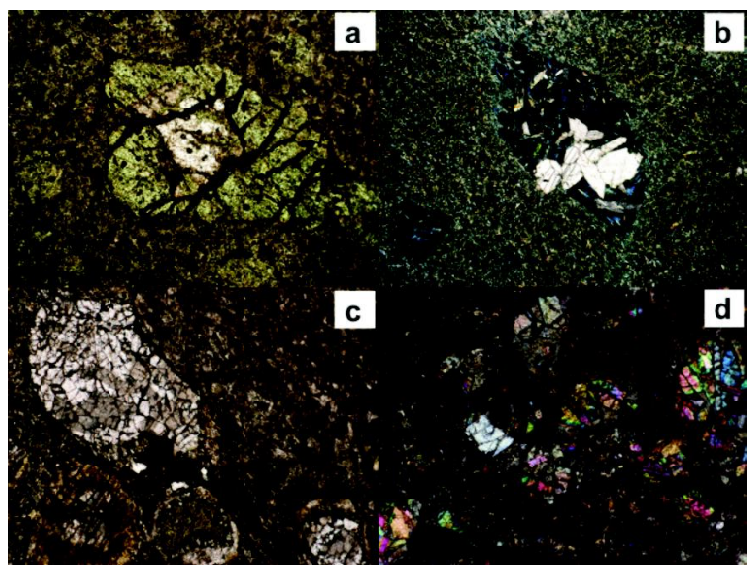

Fig. 2: Porphyritic UML, mainly olivine phenocrysts, from (a \& b) Jungel and (c \& d) Chitrangi regions. In some cases olivine grains are completely serpentinised.

lamprophyres containing olivine and phlogopite as macrocrysts and/or phenocrysts and groundmass consist of primary carbonate, phlogopite, spinel, ilmenite, rutile, perovskite, Tirich garnet and apatite (Tappe et al., 2005). 


\section{$10^{\text {th }}$ International Kimberlite Conference, Bangalore - 2012}

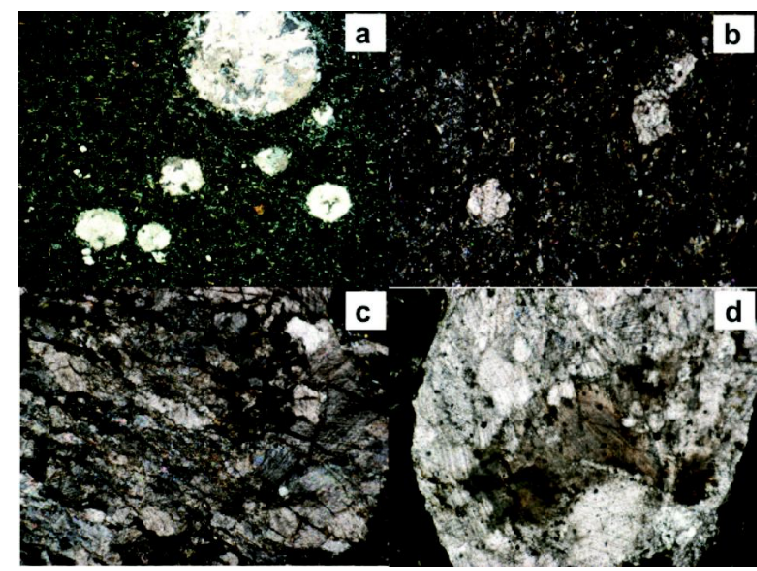

Fig. 3: Rounded carbonated ocelli clusters reported within the UML from (a) Jungel and (b) Chitrangi regions. (c \& d) Sovites from Chitrangi region. The width of all microphotographs is equivalent to $3.1 \mathrm{~mm}$

Carbonatite samples are coarse-grained sövitic in characteristics (Fig. 3c \& d). They show a hypidiomorphic to interlocking texture dominated by calcite grains and laths. Calcite is main mineral constituent however due to low-grade metamorphism dolomite is also identified. Clinopyroxene, phlogopite and olivine crystals are pseudorphed by calcite, amphibole and chlorite and present in appreciable amount.

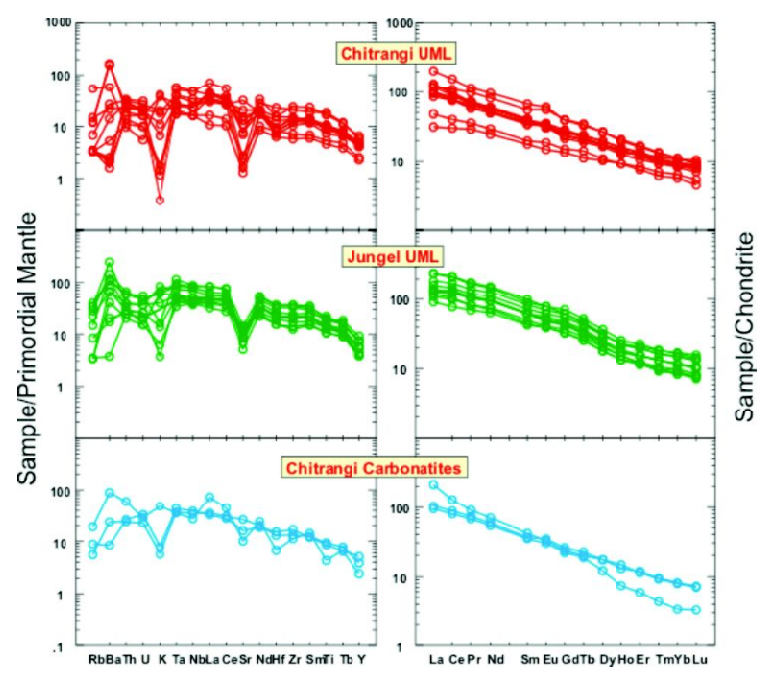

Fig. 4: Primordial mantle normalized multi-element and chondite normalized rare-earth element patterns for the Chitrangi and Jungel UML and carbonatites.
The whole rock geochemistry of the UML and associated carbonatites clearly indicate their primitive as well as evolved nature. They contain low silica and moderate alkali contents and nepheline in norms which evidently suggest alkaline nature of the studied UML. Figure 4 presents geochemical variations in these rocks. Strongly enriched light REE (LREE) patterns are exhibited by these samples.

The REE and HFSE compositions clearly indicate their similar petrogenetic nature and their magmas are not affected by crustal contamination. Absence of negative $\mathrm{Nb}$ or $\mathrm{Ta}$ anomalies in all the studied samples suggests their emplacement in an intra-continental rift tectonic setting. Enriched HFSE concentration suggests that their source was significantly enriched in these elements. Most tectonic discrimination diagrams also corroborates within-plate continental setting (Pearce and Norry, 1979; Pearce, 1982; Meschede, 1986, etc.).

Presence of a wide spectrum of undersaturated alkaline magmatic rocks comprising lamprophyres, syenites, tinguites, possibly kimberlties, and highly carbonated rocks as well as ultrabasic rocks as intrusives in the Mahakoshal supracrustal belt undoubtedly highlight the presence of a carbonate-rich palaeoto early-Proterozoic alkaline province. The UML suite described here is certainly forming an integral part of the Mahakoshal alkaline province. The petrological and geochemical data generated during this study suggest that enrichment of a depleted mantle source by percolating carbonate rich volatile and incompatible element-rich fluids from the underlying asthenosphere resulting in formation of metasomatised mantle source which, during the rifting event, produced carbonate-rich UML magma that ultimately crystallized into the aillikites. Similar UML magma production beneath an incipiently rifted cratonic area also accounts for the composition of aillikites (e.g. Tappe, et al., 2004, 2005, 2006). 


\section{0 $^{\text {th }}$ International Kimberlite Conference, Bangalore - 2012}

\section{Acknowledgements}

Senior author (RKS) would like to thank Council of Scientific and Industrial Research, New Delhi for the financial support through a Scheme 24 (0288)/06/EMR-II).

\section{References}

Blichert-Toft, J., Arndt, N. T. and Ludden, J. N. (1996) Precambrian alkaline magmatism. Lithos 37:97111.

Jain, S. C., Nair, K. K. K. and Yedekar, D. B. (1995) Geology of the Son Narmada-Tapti lineament zone in Central India. Geol. Surv. India Spec. Publ. 10: $1-154$.

Meschede, M. (1986) A method of discrimination between different types of mid-ocean ridge basalts and continental tholeiites with the Nb-Zr-Y diagram. Chem. Geol. 56: 207-218.

Nair, K. K. K., Jain, S. C. and Yedekar, D. B. (1995) Stratigraphy, structure and geochemistry of the mahakoshal greenstone belt. Geol. Soc. India Mem. 31: 403-432.

Naqvi, S. M. and Rogers, J. J. W. (1987) Precambrian Geology of India. Oxford University Press, New York, 223p.

Pearce, J. A. (1982) Trace element characteristics of lavas from destructive plate boundaries. In: R.S. Thorpe (Ed.), Andesites, Wiley, Chichester, pp.525548.

Pearce, J. A. and Norry, M. J. (1979) Petrogenetic implications of $\mathrm{Ti}, \mathrm{Zr}, \mathrm{Y}$ and $\mathrm{Nb}$ variations in volcanic rocks. Contrib. Mineral. Petrol. 69: 3347.
Rock, N. M. S. (1991) Lamprophyres. Glasgow: Blackie, 285 pp.

Roy, A. and Chakraborty, K. (2008) Precambrian Mafic-Ultramafic Magmatism in Central Indian Suture Zone. Jour. Geol. Soc. India 72: 123-140.

Roy, A., Ramchandra, H. M. and Bandyopadhyay, B. K. (2000). Supracrustal belts and their significance in the crustal evolution of central India. Geol. Surv. India Spec. Publ. 55: 361-380.

Srivastava, R. K. and Chalapathi Rao, N. V. (2007) Petrology, geochemistry and tectonic significance of Paleoproterozoic alkaline lamprophyres from the Jungel Valley, Mahakoshal supracrustal belt, Central India. Mineral. Petrol. 89: 189-215.

Tappe, S., Jenner, G. A., Foley, S. F., Heaman, L. M., Besserer, D., Kjarsgaard, B. A. and Ryan, A. B. (2004) Torngat ultramafic lamprophyres and their relation to the North Atlantic Alkaline Province. Lithos 76: 491-518.

Tappe, S., Foley, S. F., Kjarsgaard, B. A., Heaman, L. M., Jenner, G. A., Stracke, A. and Romer, R. L. (2005) Ultramafic lamprophyres and carbonatites of Labrador and New Quebec: towards a genetic model for Neoproterozoic rift-related alkaline magmatism in the North Atlantic region. ReportGeological Survey of Denmark and Greenland 68: 115-117.

Tappe, S., Foley, S. F., Jenner, G. A., Heaman4, L. M., Kjarsgaard, B. A., Romer, R. L., Stracke, G. A., Joyce, N. and Hoefs, J. (2006) Genesis of ultramafic lamprophyres and carbonatites at Aillik Bay, Labrador: a consequence of incipient lithospheric thinning beneath the North Atlantic craton. Jour. Petrol. 47: 1261-1315.

Vichi, G., Stoppa, F. and Wall, F. (2005) The carbonate fraction in carbonatitic Italian lamprophyres. Lithos 85: 154-170. 